\title{
First records of Buff-fronted Owl, Aegolius harrisii (Cassin, 1849) (Aves, Strigiformes), from the state of Maranhão, northeastern Brazil, and the northernmost record for the Cerrado domain
}

\author{
Anderson Felipe Teixeira da Silva ${ }^{1}$, Hilda Raianne Silva de Melo ${ }^{1,2}$, Flávio Kulaif Ubaid ${ }^{1,2^{*}}$ \\ 1 Laboratório de Ornitologia, Centro de Estudos Superiores de Caxias, Universidade Estadual do Maranhão, Caxias, MA, Brazil \\ •AFTS: msandysom@gmail.com (1) https://orcid.org/0000-0002-0183-3958•HRSM: hildaraianne15@gmail.com (1) https://orcid.org/0000- \\ 0003-2569-5227•FKU: flavioubaid@gmail.com @ https://orcid.org/0000-0001-8604-1206 \\ 2 Programa de Pós-Graduação em Biodiversidade, Ambiente e Saúde, Centro de Estudos Superiores de Caxias, Universidade Estadual do \\ Maranhão, Caxias, MA, Brazil \\ * Corresponding author
}

\begin{abstract}
We present the first record of Aegolius harrisii (Cassin, 1849) from the state of Maranhão, extending the known distribution of the species $283 \mathrm{~km}$ to the west in the Brazilian Northeast. This record also represents the northernmost locality of the species within the Cerrado phytogeographic domain, which coincides with the ecotone between the Cerrado, Caatinga, and Amazon domains. Given the considerable gaps in the data on the occurrence of this owl in the Brazilian Northeast, we would recommend more surveys in specific areas with similar phytophysiognomies.
\end{abstract}

\section{Keywords}

Aegolini, Caatinga, distribution, filling gap, Maranhão Babaçu Forest, range extension, Strigidae

Citation: Silva AFT, Melo HRS, Ubaid FK (2021) First records of Buff-fronted Owl, Aegolius harrisii (Cassin, 1849) (Aves, Strigiformes), from the state of Maranhão, northeastern Brazil, and the northernmost record for the Cerrado domain. Check List 17 (2) 353-358. https://doi. org/10.15560/17.2.353

\section{Introduction}

Buff-fronted Owl, Aegolius harrisii (Cassin, 1849), is the only species of its genus found in South America (Holt et al. 2020) and is one of 22 species of Strigidae known to occur in Brazil (Piacentini et al. 2015). Three subspecies are currently recognized: A. h. harrisii (Cassin, 1849), which is distributed from northwestern Venezuela to central Peru; A. h. dabbenei Olrog, 1979, found in northwestern Argentina and southern Bolivia; and A. h. iheringi (Sharpe, 1899), which ranges from eastern Bolivia and Paraguay, to eastern and central Brazil, and south to Uruguay and northeastern Argentina (Holt et al. 2020).

Until the first decade of the 21st century, A. harrisii was known only from a few localities within its wide geographic distribution, in particular in Brazil. Since then, additional data have been gathered and new aspects of the natural history of this species, including its vocalizations and habitat preferences, have been described (e.g. Braun et al. 2003; Córdoba and Ahumada 2005; Bodrati and Cockle 2006; Ubaid et al. 2012; Bravo and 
Barrio 2014; Ramoni-Perazzi et al. 2014; Ruiz-Esparza et al. 2017; Penagos et al. 2018). Although these studies have provided important insights into the ecological preferences of the species, most of its life history traits remain poorly understood, and the number and size of its populations are probably underestimated (Enríquez 2015; Girão and Albano 2010; Rosa et al. 2015).

In the Brazilian Northeast, $A$. harrisii has been recorded in the states of Alagoas (https://www.wikiaves. com.br/969427), Bahia (Studer and Teixeira 1994), Ceará (Girão and Albano 2010), Paraíba (Pereira et al. 2012), Pernambuco (https://www2.ib.unicamp.br/fnjv/ collection.php?fnjv=1338), and Sergipe (Ruiz-Esparza et al. 2017). There are, however, considerable gaps in the distributional data in the central and western portions of Northeast Region. Herein, we provide the first record of A. harrisii from Maranhão and review the available data on its distribution.

\section{Methods}

Our study was conducted in the municipality of Caxias, Maranhão, Brazil. Caxias is within the Cerrado phytogeographic domain, although it is influenced by the neighboring Amazon and Caatinga domains. Based on the classification of the world's ecoregions (Olson et al. 2001), the study area is located within the Maranhão Babaçu Forest, which also defined as a transition zone between the Amazon and Caatinga ecoregions. The vegetation of the municipality of Caxias includes a range of different phytophysiognomies, ranging from more open environments, such as the Cerrado sensu stricto (scrub savanna) to dense forest formations, such as the Cerradão (savanna woodland) and gallery forests, which are dominated by buriti palm (Mauritia flexuosa L.f.).

The team at the Centro de Estudos Superiores de Caxias, Universidade Estadual do Maranhão, Laboratory of Ornithology has monitored the bird fauna of Caxias since January 2017 in a number of forest fragments within the municipality. During this time, we sporadically made nocturnal surveys, typically one night every three months.

The locality of our new records reported here has a gently sloping relief, covered with predominantly secondary vegetation that has a mean canopy height of 15 $\mathrm{m}$. The dense understory is dominated by vines and lianas, with abundant tucum palm (Astocaryum G.Mey.). During the rainy season, the saturation of the water table makes the area swampy, with the water draining off slowly into temporary ponds or nearby reservoirs. The vegetation is densest in the low-lying areas where the canopy is higher, whereas on the higher ground, grasses and small trees predominate, with exposed soil in some areas. There are a number of small villages in the surrounding area, where slash-and-burn subsistence farming is common, in addition to areas of cattle pasture.

We compiled available distributional data on A. harrisii from the literature and the ornithological collections (Table 1) of the Museu Paraense Emílio Goeldi (MPEG; Belém, Brazil) and the Museu de Zoologia da Universidade de São Paulo (MZUSP; São Paulo, Brazil). We also consulted six online databases: Macaulay Library (2020), WikiAves (2020), Xeno-canto (2020), speciesLink (2020), Global Biodiversity Information Facility (GBIF.

Table 1. Records of Aegolius harrisii from the Brazilian Northeast. Only the oldest reference and/or voucher is shown for localities when more than one record is available. Numbers in Map column are linked to Figure 2.

\begin{tabular}{|c|c|c|c|c|c|c|c|}
\hline Map & Latitude & Longitude & Locality & Municipality & State & Year & Author(s) / voucher ${ }^{\dagger}$ \\
\hline$\star$ & -04.9500 & -043.4661 & Araras & Caxias & Maranhão & 2018 & Present study / ML268699911 \\
\hline 1 & -09.7494 & -037.4352 & Unspecified* & Pão de Açúcar & Alagoas & 2013 & Têia, P/WA969427 \\
\hline 2 & -09.2325 & -038.9041 & Unspecified* & Macururê & Bahia & 1974 & Vielliard, J/ FNJV1341 \\
\hline 3 & -012.6972 & -038.3330 & Vargem da Meira & Camaçari & Bahia & 1985 & Studer and Teixeira (1994) \\
\hline 4 & -014.5313 & -040.3650 & Unspecified* & Poções & Bahia & 2018 & Gonçalves, M / WA3103058 \\
\hline 5 & -014.4119 & -040.1161 & Unspecified* & Boa Nova & Bahia & 2000 & MZ76481 \\
\hline 6 & -013.5608 & -044.7980 & Unspecified* & Correntina & Bahia & 1993 & Antas et al. (1993) \\
\hline 7 & -04.8530 & -039.5744 & Unspecified* & Madalena & Ceará & 1975 & Vielliard, J / FNJV1339 \\
\hline 8 & -04.1000 & -039.0500 & Inhuporanga & Caridade & Ceará & 1990 & Studer and Teixeira (1994) \\
\hline 9 & -07.2330 & -039.5000 & Chapada do Araripe & Crato & Ceará & 1996 & Girão and Albano (2010) \\
\hline 10 & -04.4836 & -039.5841 & Serra do Machado & Canindé & Ceará & 2004 & Girão et al. (2007) \\
\hline 11 & -04.5000 & -039.5666 & Unspecified ${ }^{*}$ & Itatira & Ceará & 2004 & Girão, W / XC6421 \\
\hline 12 & -04.2405 & -038.9397 & Serra de Baturité & Guaramiranga & Ceará & 2007 & Girão et al. (2006) / XC10624 \\
\hline 13 & -03.5400 & -040.4536 & Unspecified* & Meruoca & Ceará & 2010 & Brito, C/ XC329839 \\
\hline 14 & -03.8113 & -039.4736 & RPPN Mãe-da-Lua & Itapagé & Ceará & 2012 & Reides, H / WA571064 \\
\hline 15 & -05.1416 & -040.9161 & Serra das Almas & Crateús & Ceará & 2019 & Girão, W / WA3528147 \\
\hline 16 & -07.3563 & -037.6136 & Unspecified* & Imaculada & Paraíba & 2009 & Pereira et al. (2012) \\
\hline 17 & -07.9822 & -038.2894 & Unspecified* & Serra Talhada & Pernambuco & 1975 & Vielliard, J/ FNJV1338 \\
\hline 18 & -08.8827 & -036.4969 & Fazenda Fojos & Garanhuns & Pernambuco & 2018 & Oliveira (2018) / WA2978376 \\
\hline 19 & -010.7466 & -037.3769 & Parque dos Falcões & Itabaiana & Sergipe & 2014 & Ruiz-Esparza et al. (2017) \\
\hline
\end{tabular}

*Unspecified localities were georeferenced at the municipal seat.

†Fonoteca Neotropical Jacques Vielliard (FNJV), Macaulay Library (ML), Museum of Zoology of the University of São Paulo (MZ), WikiAves (WA), Xeno-canto (XC). 
org 2021), and Fonoteca Neotropical Jacques Vielliard (2020). We also revised the inventory of the bird fauna of the state of Maranhão, based on Oren (1991), together with the new records from the sources identified above. We produced the map in QGIS v. 3.14 Pi (QGIS Development Team 2020). We deposited our photograph of $A$. harrisii in the Macaulay Library (2020) database and the voice recording in the Xeno-canto (2020) database.

\section{Results}

\section{Aegolius harrisii (Cassin, 1849)}

Figures 1-3

New records. BRAZIL - Maranhão - Caxias, Araras Village; $-04.9500,-043.4661 ; 100$ m a.s.1.; 5.V.2018; 1 adult; ML268699911 • same locality; 1.VI.2018; 1 adult; XC570829.

One individual (Macaulay Library: ML268699911) was a single bird vocalizing spontaneously at the forest edge adjacent to a dirt road. It was perched in the tree subcanopy at a height of $6 \mathrm{~m}$, where it vocalized for approximately $10 \mathrm{~min}$. The other individual (XC570829) was also observed alone in its perch in a tree at a height of $8 \mathrm{~m}$. It responded to playback by vocalizing and observed for approximately $30 \mathrm{~min}$ before it flew away into the forest.

Identification. We identified $A$. harrisii by a set of remarkably diagnostic features which include: the characteristic vocalization unlike any other species in the region; the facial disc outlined in black with buff trim which contrasts with the dark head; the yellowish-buff forecrown and collar on the hindneck and chocolate-brown upperparts; the brown lores to the base of the bill; the blackish tail, with two broken, white bars and white tip; the primaries notched with white and the wing-coverts with white spots; and the tarsi feathered cream-yellow.

\section{Discussion}

Our new records represent an extension of the geographic range of $A$. harrisii by approximately $283 \mathrm{~km}$ to the northwest of the nearest previous record at Crateús, in Ceará state. In northeastern Brazil, A. harrisii has been recorded previously from the states of Bahia, Ceará, Pernambuco, Paraíba, Alagoas, and Sergipe (Table 1; Fig. 2), but not in Maranhão.

Aegolius harrisii was first recorded in northeastern Brazil in 1974, in the municipality of Macururê, Bahia (Fonoteca Neotropical Jacques Vielliard: FNJV1341). Since this initial record, A. harrisii has been reported regularly from new localities within the region (Fig. 3 ). It has only been in the past five years, however, that the first records have been obtained from the state of Alagoas (Rodrigues 2013) and the Atlantic Forest of

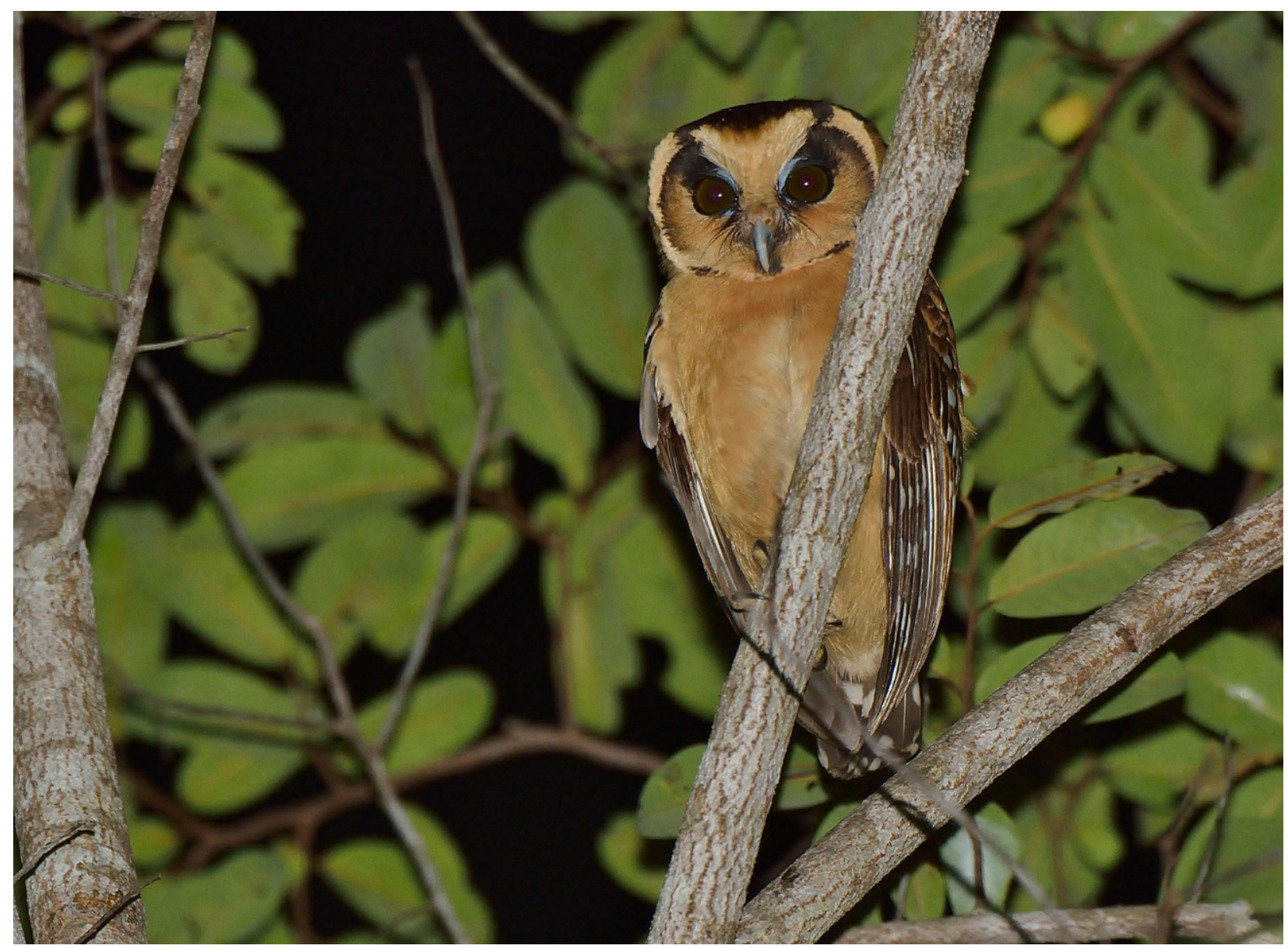

Figure 1. Aegolius harrisii (ML268699911) from municipality of Caxias, state of Maranhão, Brazil. 


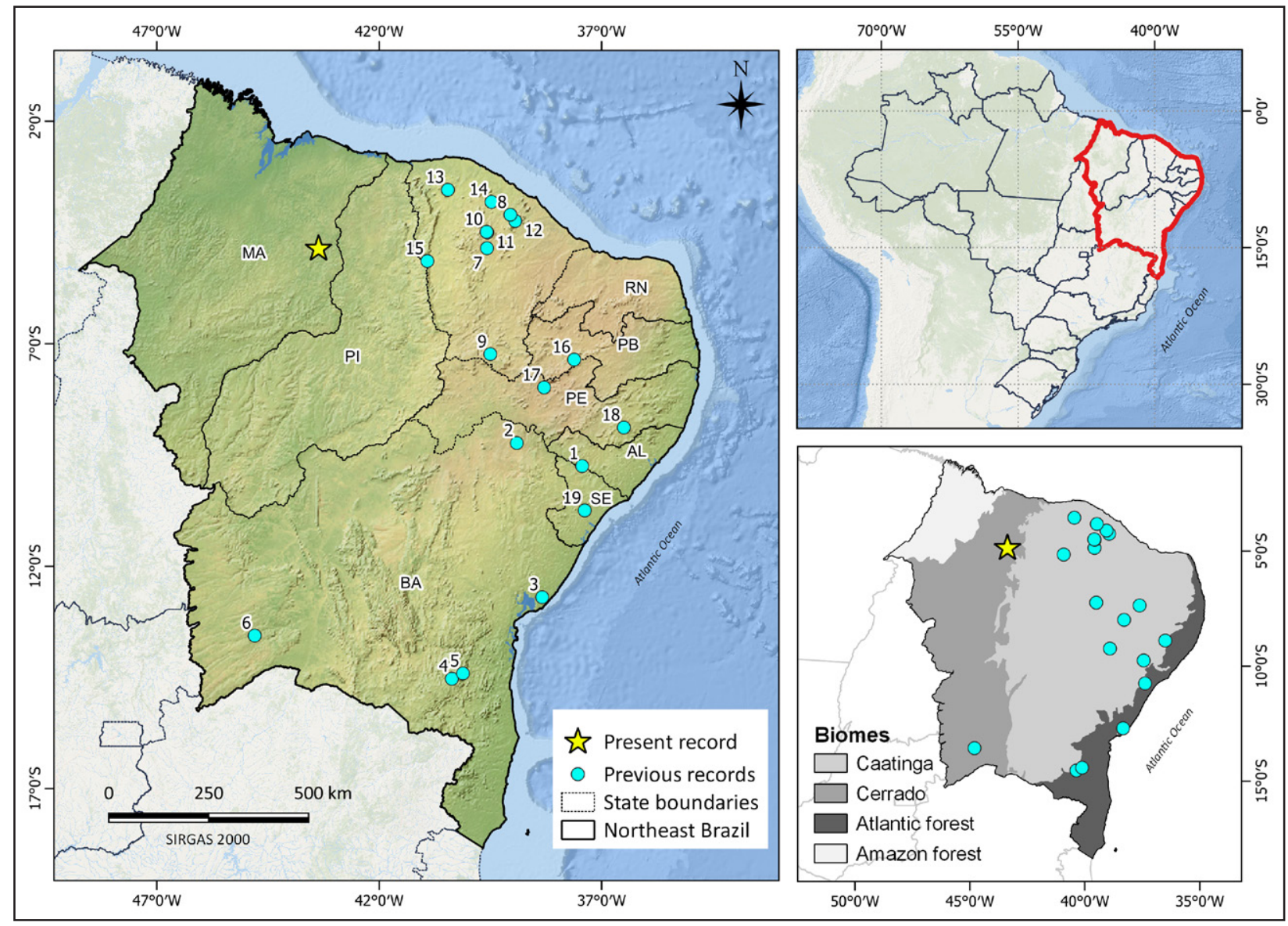

Figure 2. Localities of Aegolius harrisii in northeastern Brazil. Blue circles indicate the existing records; the star shows the new locality in the state of Maranhão.

Sergipe (Ruiz-Esparza et al. 2017). In Pernambuco (Oliveira 2018) and Alagoas (Rodrigues 2013), A. harrisii has been documented by photographs but without additional information provided on the habitat. From the state of Paraíba, this species was first recorded in an area of
Caatinga (Pereira et al. 2012), as in the municipality of Serra Talhada Pernambuco, where A. harrisii was first recorded in 1975 by the ornithologist Jacques Vielliard (Fonoteca Neotropical Jacques Vielliard: FNJV1338).

Records of $A$. harrisii from the Brazil Northeast are

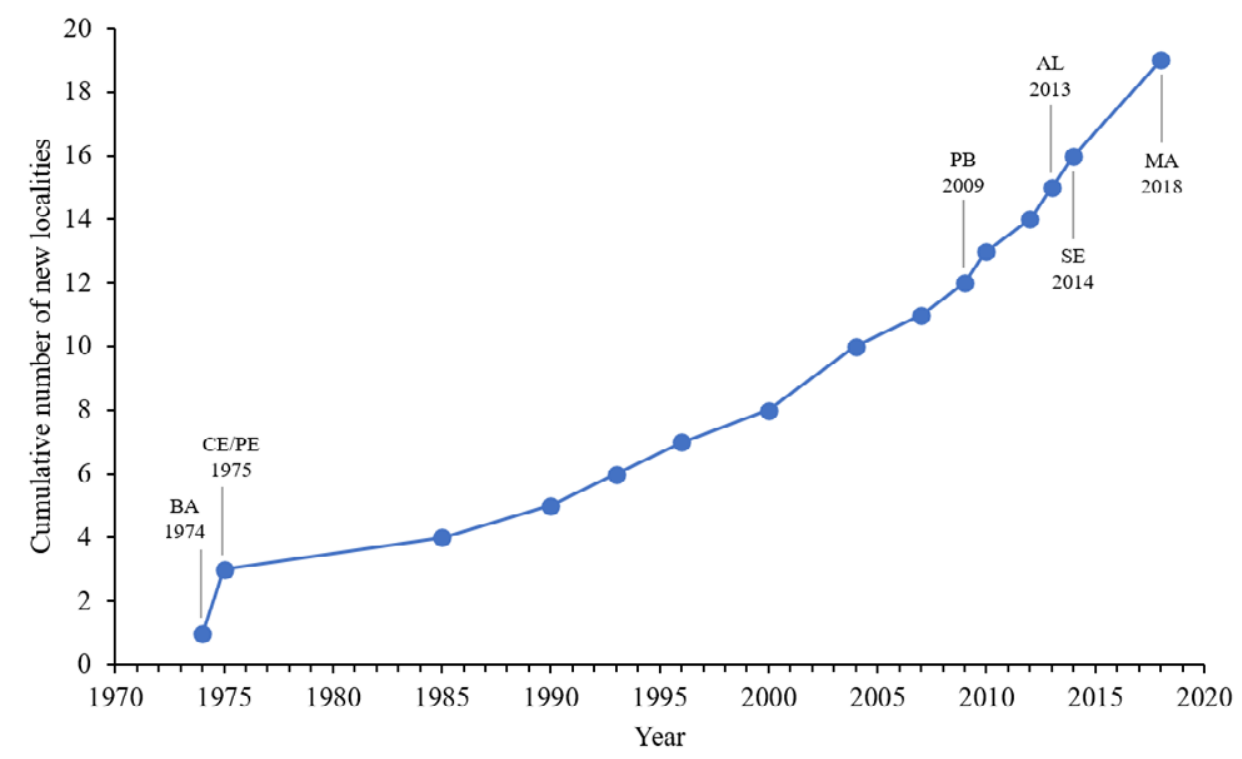

Figure 3. Cumulative number of the new occurrence localities of Aegolius harrisii in northeastern Brazil. The dots on the line indicate the year of the first record in the respective state. Bahia (BA), Ceará (CE), Pernambuco (PE), Paraíba (PB), Alagoas (AL), Sergipe (SE), and Maranhão (MA). 
concentrated in the region's Caatinga and Atlantic Forest domains, with only two records from the Cerrado (Antas et al. 1993; new records). A prominent gap exists in the central-western portion of this region (Fig. 2), and the occurrence of $A$. harrisii in the states of Rio Grande do Norte and Piauí has yet to be confirmed.

Aegolius harrisii appears to prefer arboreal vegetation of varying densities and with a low canopy, including riparian forest and forest edges and at different stages of succession (Kaminski 2009; Santos 2009; Girão and Albano 2010; Rebelato et al. 2011; Ubaid et al. 2012; Rosa et al. 2015; Santos et al. 2014; Dornas et al. 2017). While little is known of the ecological requirements of this species, it does appear to be relatively flexible and able to occupy a wide range of varied phytophysiognomies. In São Paulo state, A. harrisii has been recorded in small fragments of Cerrado within a mosaic of gallery forests and plantations of Pinus L. and Eucalyptus L'Hér., which indicates that this species may tolerate a certain level of habitat disturbance (Ubaid et al. 2012). In Goiânia, Goiás, this owl was observed occupying a hole in the trunk of a macaúba palm (Acrocomia aculeata (Jacq.) Lodd ex R.Keith) in a deforested area near the urban zone (Dornas et al. 2017). These findings are relatively consistent with our study, in which $A$. harrisii was recorded in fragments of secondary forest in the vicinity of an anthropogenic landscape of villages and pastures.

Enríquez (2015) concluded that one of the factors determining the major gaps in the known distribution of $A$. harrisii was the fact that the behavior of the species is relatively discreet and poorly known, which may mean that it is often overlooked during surveys. In addition, Ubaid et al. (2012) pointed out that the vocalization of this owl is similar to those of a number of amphibian species, with which it may be confused, especially when heard over a distance.

The scarcity of basic ecological data for most Brazilian owls is one of the principal obstacles for the development of adequate plans for the management and conservation of owl species (Motta-Júnior 1996). Our new Maranhão records of $A$. harrisii represent an important first step toward the understanding of the habitat preferences of this species in the transition zone between three of the Brazil's principal biomes. Ultimately, we hope that this study provides an incentive for more systematic surveys within the areas of northeastern Brazil that lack data, including the major gas in Bahia and Maranhão, as well as in Piauí and Rio Grande do Norte.

\section{Acknowledgements}

We are grateful to our colleagues from the Laboratory of Ornithology for their assistance in the field. We are also grateful to the Maranhão State Foundation for Research and Scientific and Technological Development (FAPEMA - process UNIVERSAL-00798/18) for financial support. Paulo de T.Z. Antas provided valuable details on the record from Correntina, Bahia, and Luís
F. Silveira helped with information on the specimens deposited in the MZUSP. Stephen Ferrari kindly reviewed the English version of the manuscript. Finally, we express our thanks to two anonymous reviewers for their comments and suggestions that improve the manuscript.

\section{Authors' Contributions}

AFTS, HRSM and FKU wrote the manuscript; FKU prepared figures, photographed, recording, deposited the media in online databases, and revised the draft.

\section{References}

Antas PTZ, Cândido-Jr JF, Reinert BL, Pinheiro RT (1993) Lista das aves da Fazenda Jatoba, Correntina, BA. In: Cirne MP (Ed.) Resumos do III Congresso Brasileiro de Ornitologia, Universidade Catolica de Pelotas (UCPEL) e Sociedade Brasileira de Ornitologia (SBO), Pelotas, 29.

Bodrati A, Cockle K (2006) New records of rare and threatened birds from the Atlantic Forest of Misiones, Argentina. Cotinga 26: 20-24.

Braun MJ, Robbins MB, Milensky CM, O'Shea BJ, Barber BR, Hinds W, Prince WS (2003) New birds for Guyana from Mts Roraima and Ayanganna. Bulletin of the British Ornithologists' Club 123 (1): 24-33.

Bravo AG, Barrio J (2014) New distribution records of the Bufffronted Owl Aegolius harrisii Cassin, 1849 (Aves: Strigidae) in Peru. Check List 10 (1): 156-159. https://doi.org/10.15560/10.1.156

Córdoba S, Ahumada JA (2005) Confirmation of Buff-fronted Owl Aegolius harrisii for the Cordillera Oriental of Colombia. Bulletin of the British Ornithologists' Club 125 (1): 56-58.

Dornas T, Agne CE, Kajiki LN, D’Acosta N, Borges K (2017) Extensão da distribuição geográfica de Aegolius harrisii na região central do Brasil: registros inéditos para estados de Goiás e Tocantins. Atualidades Ornitológicas 196: 18-22.

Enríquez PL (2015) Los búhos neotropicales: diversidad y conservación. El Colegio de la Frontera Sur, San Cristóbal de Las Casas, Chiapas, México, 630 pp.

Fonoteca Neotropical Jacques Vielliard (2020) Coleções Audiovisuais. Coleção de Sons. https://www2.ib.unicamp.br/fnjv. Accessed on: 2020-10-13.

GBIF.org (2020) GBIF home page. https://www.gbif.org. Accessed on: 2020-10-20.

Girão W, Albano C (2010) Sinopse da história, taxonomia, distribuição e biologia do caboré Aegolius harrisii (Cassin, 1849). Revista Brasileira de Ornitologia 18 (2): 102-109.

Girão W, Albano C, Pinto T, Silveira LF (2007) Avifauna da Serra de Baturité: dos naturalistas à atualidade. In: Oliveira TS, Araújo FS (Eds.) Biodiversidade e conservação da biota na serra de Baturité, Ceará. Edições UFC/Coelce, Fortaleza, Brazil, 187-224.

Holt, DW, Berkley R, Deppe C, Enríquez PL, Petersen JL, Rangel Salazar JL, Segars KP, Wood KL, Bonan A, Marks JS (2020) Bufffronted Owl (Aegolius harrisii), version 1.0. In: del Hoyo J, Elliott A, Sargatal J, Christie DA, Juana E (Eds.) Birds of the world. Cornell Lab of Ornithology, Ithaca, New York, USA. https://doi. org/10.2173/bow.bufowl1.01

Kaminski N (2009) Primeiro registro documentado de Aegolius harrisii para o Estado de Santa Catarina, Brasil. Cotinga 31: 79.

Macaulay Library (2020) The Cornell Lab of Ornithology. Macaulay Library. https://www.macaulaylibrary.org. Accessed on: 2020-10-10.

Motta-Júnior JC (1996) Ecologia alimentar de corujas (Aves, Strigiformes) na região central do Estado de São Paulo: biomassa, sazonalidade e seletividade de suas presas. PhD dissertation, Universidade Federal de São Carlos, São Carlos, Brazil, 119 pp.

Oliveira AJ (2018) WA2978376, Aegolius harrisii (Cassin, 1849). 
WikiAves: a enciclopédia das aves do Brasil. http://www.wikiaves. com/969427. Accessed on: 2020-10-14.

Olson DM, Dinerstein E, Wikramanayake ED, Burgess ND, Powell GVN, Underwood EC, D'Amico JA, Itoua I, Strand HE, Morrison JC, Loucks CJ, Allnutt TF, Ricketts TH, Kura Y, Lamoreux JF, Wettengel WW, Hedao P, Kassem KR (2001) Terrestrial ecoregions of the world: a new map of life on Earth. Bioscience 51 (11) 933-938. https://doi.org/10.1641/0006-3568(2001)051[0933:teotw a]2.0.co; 2

Oren DC (1991) Aves do estado do Maranhão, Brasil. Goeldiana Zoologia 9: 1-55.

Penagos AP, Martínez A, Rodríguez-Bolaños A (2018) Nuevo registro y ampliación de distribuición del búho bicolor (Aegolius harrisii) in Colombia. Biota Colombiana 19 (2): 140-146. https://doi org/10.21068/c2018.v19n02a13

Pereira GA, Lobo-Araújo LW, Leal S, Medcraft J, Marantz CA, Toledo MTF, Araújo HFP, Albano C, Pinto T, Santos CHA, Serapião LCH, Silva GBM, Pioli D (2012) Important bird records from Alagoas, Pernambuco and Paraíba, north-east Brazil. Cotinga 34: $17-22$.

Piacentini VQ, Aleixo A, Agne CE, Mauricio GN, Pacheco JF, Bravo GA, Brito GRR, Naka LN, Olmos F, Posso S, Silveira LF, Betini GS, Carrano E, Franz I, Lees AC, Lima LM, Pioli D, Schunck F, Amaral FR, Bencke GA, Cohn-Haft M, Figueiredo LFA, Straube FC, Cesari E (2015) Annotated checklist of the birds of Brazil by the Brazilian Ornithological Records Committee / Lista comentada das aves do Brasil pelo Comitê Brasileiro de Registros Ornitológicos. Revista Brasileira de Ornitologia 23 (2): 91-298.

QGIS Development Team (2020) QGIS Geographic Information System. Open-Source Geospatial Foundation Project. http://qgis.os geo.org.

Ramoni-Perazzi P, Soto-Werschitz IA, Bianchi-Pérez G, Jones J, Ruíz-Ramoni D, Molina M, Muñoz-Romo M, Correa I (2014) Noteworthy records for the avifauna of the Cordillera de Mérida, Venezuela. Cotinga 36: 2-11.

Rebelato MM, Cunha GG, Machado RF, Hartmann PA (2011) Novo registro do caburé-acanelado (Aegolius harrisii) no Bioma Pampa, sul do Brasil. Biotemas 24 (1): 105-107. https://doi.org/10.5007/21 75-7925.2011v24n1p105

Rodrigues PP (2013) WA969427, Aegolius harrisii (Cassin, 1849). WikiAves: a enciclopédia das aves do Brasil. http://www.wikiaves. com/969427. Accessed on: 2020-10-14.

Rosa RD, Silveira JC, Crozariol MA, Menq W, Vabo M (2015) Primeiros registros documentados do caburé-acanelado Aegolius harrisii (Cassin, 1849) para o Vale do Paraíba e Serra da Mantiqueira, São Paulo. Atualidades Ornitológicas 183: 6-8.

Ruiz-Esparza J, Costa JPM, Santos C, Ruiz-Esparza DPB, BeltrãoMendes R, Ferrari SF (2017). Range extension for Buff-fronted Owl Aegolius harrisii in north-east Brazil and a case of Heterochromia iridis in Strigidae. Bulletin of the British Ornithologists' Club 137 (1): 91-93. https://doi.org/10.25226/bboc.v137i1.2017.a8

Santos KK, Miguel M, Lombardi VT (2014) Novos registros do caburé-acanelado Aegolius harrisii (Cassin, 1849) para o estado de Minas Gerais e comentários sobre sua biogeografia. Atualidades Ornitológicas 181: 7-11.

Santos REF (2009) Ampliação da distribuição de Aegolius harrisii a partir de coleta por atropelamento. Atualidades Ornitológicas 147: $46-47$.

speciesLink (2020) speciesLink. http://www.splink.org.br/. Accessed on: 2020-10-20.

Studer A, Teixeira DM (1994) Notes on the Buff-fronted owl Aegolius harrisii in Brazil. Bulletin of the British Ornithologists' Club 114 (1): 62-63.

Ubaid FK, Maffei F, Moya GM, Donatelli RJ (2012) Range extension for Buff-fronted Owl Aegolius harrisii in south-east Brazil. Bulletin of the British Ornithologists' Club 132 (3): 175-179.

Xeno-canto (2020) Xeno-canto. https://www.xeno-canto.org. Accessed on: 2020-10-18.

WikiAves (2020) Mapa de registros da espécie caburé-acanelado (Aegolius harrisii). WikiAves: a enciclopédia de aves do Brasil. https://www.wikiaves.com.br/mapaRegistros_cabure-acanelado. Accessed on: 2020-10-15. 